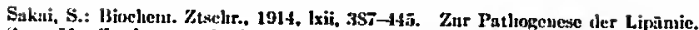
s:ass, M.: Ztselit. exp. 1'uth. u. Ther., 1914, $x v, 370-378$. Die Aerulenung der

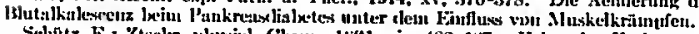

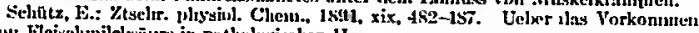
vout Fleiselumilel wiure in pa thologiselien llarmen.

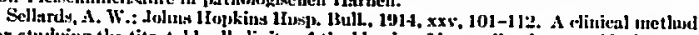
for studying the titratalile nlkaliunty uf the blowl anil itsapolication to acidosis.

Seo, Y.: Arch. exp. Patli. u. Pharm.. 1909, 1xi, 1-6. Uelet das Vorkummet von Linōntic und uber die Meuge der Lipoidsulest:tuzen in Blit und Leber bein Pitlkreasdiabetes.

Stadelnann, E.: Areli. f. exp. Path. U. Plarni., 1AS3, xvii, 419-4t4. Veler die Uraselien der pathologischeis Anmoniakaussseheidung bein Dialsetes mellitus und les Consa dialsetieutu.

Taylur, A. E.: University of Califoruia Publications, Pathologs, So. 7, i, 71-86, Situdies on th ash-frec diet. Digestion nud Metalolisn, Lea and Felsiger, 1912.

Terroine, F. F.: Juur, de plyysist. et de path. Rín.. 1914, xvi, 3S6-397. Varistions lipwrnloblesterinemiques an cours ale l'inunition et de l'alimentation.

Thiroloix. J., and Jarol, P.: Bull. et inént, de la Sice. méd. des hôn. de Paris, 1910,

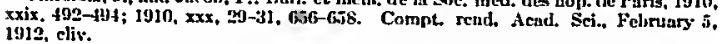

Tyson, J.: A Treatice on Irrizht's Divease and Disletes, l'hiladelphia, 1581.

Viulerliall, F. P.: Jour. IBiol. Chen., 1913, xx. Studies on the nretalsolisn of umnonium silts, Jour. IBiol. Chetu., vols, $x, x v i, x \times$ (Hydraziac).

Van Slyke, D. D.: Proc. Soc. Exp. Iliol. anI MIed., 1916, xiii, 134. Gravinetric aleternituation of beta-oxybutstic acid.

Vuu Siske, D. D., Stillnan, E., and Culleu, G. E.: Proc. Soc. Exp. Niol. and Xled., 1915, xii, 165 -16G. The nature and deteetion of dialet it acidosis. (Also fortheoniug iullieation in Jour. Biol. Clren.).

von Mlering, J.: Zttseltr. f. klin. Ifed., 1868, xiv. 405-423. Ueher Dinhetes mellitus. 1hid. 1850, xvi, 4.11-146, Ueber Dialsetes mellitizs.

ron Nonrden, C.: Handbucls der Pathologie des Stofreclesels, Berlin, 1906, n. 3333. Dic Zuekerkranklieit, Berlin, 1912, 10. 1s0.

Wakeusat. A. J., nnd Dalin, II. D.: Jour. Biul. Client., 1909, vi, 373-359. On the decoulposition of $\beta$-oxyluntyric acid tnd uretomacetic acid by ellaymes of the

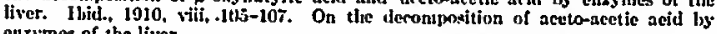
ellyytmes of the liver.

Wialdvogel, R., and Ilagenlera. J.: Z̈tschr. 1. klin. Mlel., 1001, xlii, 443-150. Ueler alimetitive Acetonutic.

Wulter, F.: Arel. exp. Path. u. Pharm., 15\%, vii, ItS-178. Unterstelungen niler die Wirkung der Sajuren auf den thicrischen Orennismug.

Weintraud, W.: Bibliotleca medica. 18y3. Untesuchungen aber den Stoffweclreel im Dialsetes mellitus und zur diatetisehen Therapie der Kranklieit.

Woodyatt, It. T.: Jour. Ant. Med. Assn., Jume 17. 1916. Ixvi, 1910-1913. Acilonis in Dialsetes. Jour. Biol. Chem., voly. $x x$, xxi, and xxiv. The Harvey Lectures, 1915-1016.

Zawilski: Arl. d. Leipx. Plyssiol. Inst., 1576, 147. Ref. by Magnug-Levy anl Meyer. Daner u. Umfang d. Fettstromes durch d. Ductus thoracicus.

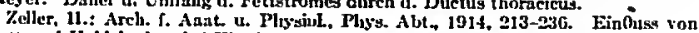
Fett unil killelrydmi leei Eiweisshunger aul die Stickstoffallsscheidung.

\title{
ENDOTHELIOMA OF THE RIGHT BRONCHUS REMOVED BY PERORAL BRONCHOSCOPY.'
}

\author{
Br Chevalaen Jacksox, MI.D.,
} pittsuUtegl, $\mathrm{m}$.

H.:

Tile patient wats referred to the author by Dr. J. P. Ilarley, of Williamsport, P'a., who stated that there were sigus of a localized

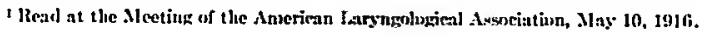


patlology in the right bronelous and right lower lobe whiell, in his opinion, wis not tuhurculous and was otherwise so unusual as to demand a diagnostic hronchoseopy. "The putient's statement (to Dr. Harley.) that he luad "a sensation as of a 'ball ralve' in the right broneluus slutting off lis l,reath, at times when breatling in, at other times when breathing out, impressed the anthor with the illea that the patient was a nenrasthenic, in view of whicl u dingnostie bronchoscopy did not seem justifiable. The outcome showed this opinion erroneous. The following is the history:

CASE Histonr.-Mlr. F., aged thirty-five years, oceupied as a elerk at a desk and around a faetory, had had good health until five years ago. Ilt health started with a "heavy cold" lasting one year; then lie spat blond. Symptoms were less during summer. Fivery winter's curl and spring, symptoms were worse, starting as "licavy cold" and ending in ill health. Patieut refers seusations ("restriction, swelling, compression, wheczing") to lis right side. Wheezing audible with mouth open, worse after cxipcetoration. Breatling never seems normal. Has scusatiou of secretiou in bronehi, also sersation of "flapping" at times. Also a sensation as of a ball valve suddenly shutting of sometimes inspiration, at other times expiration. Twice yearly las cycle of the following symptoms in the order given: (1) Cold in head. (2) Tightuess in cliest. (3) Cough. (4) Slight expectoration. (5) Free cxpectoratiou. (6) Blcesing, which formerly amounted to about a fourth of a cupful, and was follorred in a few days by expectoration of blood clots. Recently only blood streaks were noticed in expectorntion.

IIe spent two years in a sanatarium for thc tuberculous. Discharged because no bacilli could be found in sputum, but cough and wheezing persistel. Roentgen-ray examination and sputum examinations, guinea-pig inoculation, Wassermann and therapeutic luetie tests at a large eastem hospital, were all negative. Dingnosis then made: cnlarged hronehial gland. So treatment was benefieial. No sputum test lıad been made during the last tweive montlss. Bronehoscopy by soneone was negative. Septum deflecterl by "foul tip" at basball some jears previously: Septal aperation ly" Dr. Ritter eured persistent healaehes.

Diagnoses of various clinicians prior to coming under observation of Dr. Ifarley were: tuberculosis, clronic right-sirlerl hronchitis; monolateral (right) asthma; eompression stenosis of right bronchus, probably caused by adenopatly;. Dr. J. Chalmers I a Costa lead made what ultimately proved to be a correct diagnosis of obstruetion of the right bronehus.

Report of Sputum Examination by Dr. Ernest W. Willetts. "Very" careful repeated examinations for tuberele baeilli botlı by clireet smears and also by antiformin methor failed to show them. '. The sputum contains some small whitish masses of solid matter, which, on examination, slowed maly large cells of varying slapes. Some 
oval, some spindle-form and others poligonal. They are unlike any of the eells ordinarily seen in sputum and are so like cells from a new growth that a diagnosis of tnmor is, I beliere, justifiable."

lieport of Dr. George C. Jolmston. First Fluoroscopy. Fibrosis of right lower lobe bronehus. I'atichnt preseuted sy'mptoms of unilateral asthma on fluoroscopic examination. Ieft lung and diaphragm normal; parts were normal in size, shape, and position. TFight upper lobe normal, but beginning abont one ineh belor bifureation a trefoil-shaperl shadow extending downward was seen. The diaphragm on the right side conld not be distinguished. The lower lobe of the lung was replaced by a shadow having exactly the opaeity of the liver. It was impossible to state where the liver ended and the lumg begant. The appeamnee was that of an unresolved pneumonia. 'This portion of the ling could not be made to light up on deep respiration or congling. No motion of the right portion of the diaphragin could be seen nor could its position be located.

Sccond Fluoroscopy. At a second examination two days later a considcrable change hat accurrel. Some portions of the dense shadow were elear, showing that the lower lobe was occasionally reeeiving small quantities of air. The clingnosis of ateleetasis due to right bronehial obstruction was made, and diagnostie bronehoscopy was strongly urged.

Mocntgenographic examination (Fig. 1) showed an opaeity of the lower lobe continuous with the hepatic opacity, the dome of the diaphragm on the right side being iulistinguishable.

I'hysical Examination by Dr. John J\%. Boyce. At the date of the first examination there was some contraction of the right side and a slight impairment of pereussion wote, both of them eorresponding to extreme expiration as though the air eould not get in. Vesienlar sound was suppressed and replaced by large wheczing rales. There mas eriflently obstruction in the right main bronchus, alfecting inspiration more than expiration at this particular time. There was some impairment of supracirdine resonince nnd also an inereased area of conduction of whispered voice at the back; but both of these signs (suggestive of bronelinal aulenopathy) extended rather to the left than to the right.

Anemrysm or other meliastimal tomoor liaving been excluded, we have to consider the possibility of a single lymphatie gland makiug pressure on the hrouchus. This diagnosis has been snggested by an expert elinieian. Against it is the fact thit there is no evidence of bronchial aclenopatly. Sor can we conceive how pressure from without eonlh exert it valvular effeet, occisionally reversiog the direction of the valvular action. The sane considerations apply to organie stricture almost locrmetically tight, large caliber strietures being latent as regards dyspnea. The loug duration of attaeks seemerl to exchule spasmoslic stricture.

vol. 153 , No. 3.-MAnct, 1917. 
It remined then for us to consider transparent forcign body and perlnneulated intrabronchial growth. Dr. Jachson theoretically excluclel the former on the gromd that it movable foreign body in the open bronchus would certainly prodluce purulent sputum and foul breith in less thin five reirs' time. This narrowed down the dingnosis to in movable intrahronehial tumor. The only objection to this diagnosis is, as Dr. George C. Johnston expresseel it, that it " explained every item of the history and plysical eximnintion too nicely:" Clinical diagnoses and pathological conditions rarely fit so precisely.

Branchascopy. Cintler bocil amesthesia I passed a $9 \mathrm{~mm}$. bronehoscope. A moderate innomt of secretion was eneountercl coming upwilrd from the right bronchis. When this was deared awily and the bronchoscope was insertel into the right bronchus to the point where the image shown at B, in Fig. 2 , should normally appear the tumor (A) came into view. The tumor filled a dilatatian of the right stem bronchus and sprang from the right brouchial wall, just above the orifice of the middle-lohe broncluus.

The history of five years' duration, the smooth shining surface, slightly nodular slape, aud the fact of the tumor having made for itsclf is dilatation of the broucluns, leal the anthor, in consultation witl Dr. Ellen J. Patterson, to conclude thist the growth wis benigu, prohably fibromatous, aud to ndvisc immedinte removil withont withlrawial of the liranehoscope. The piticut gave his cousent hy a slight uod, and the growth was extirpated iu n few minutes by successive nips of the bronchoscopic tissuc forceps. The bleerling wats not severc; possibly as much as two ounces of l,ood were expectoraterl. The temperature rose to $102.2^{\circ} \mathrm{F}$. the fulse to 9S, the respiratious to 30 . All came to normal in ahout one weck. Espectoration of blook-stained pus gradually diminished until it disippeared at the end of alout four weets. The pitient lais liad uminterrupted good lealth until the present time-nine montlss. The present condition of the patient is thus reported ly: I)r. Harley:

"In replying to you regarding Mr. F's. comlition, I wish to say the worl "fine" does not half express his gond condition. Ile has gained twenty-six pounds in weight; hins enjoyed the best health this winter for six years, not having the shightest bronehial affection all winter; just feeling at the "top of the heap" cver since his operntion. I feel sure he is gratefnl to you every day of his life for this inost runarkahle enre."

Report of Ilistolngienl Exominatiom of Tmmor by Dr. Ernest IT. Millefts:

"Frozen sections show a very cellular structure which presents the geoeril apptirninces of an endothelial growtli, although in some areas there are appearanees that indicate epithelial origin. Ninclenr changes are not marked, hut the growth is so cellular and infiltrates 

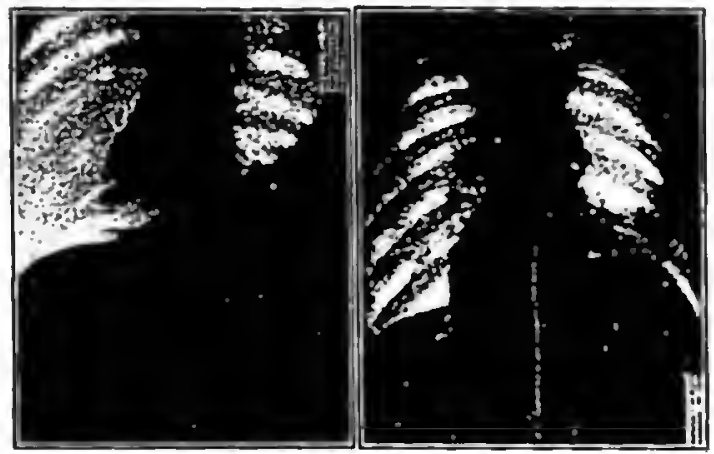

Fro. 1.- Roeatgenogram showing (on left) opacity of lower lobe of right lung, duo to obstruction of right bronchus by tumos shown in Fig. 2 . Tho right-band gitle of illuatration shows roentgenogrum taken after peroral bronchoscopic removal uf tumor.


Fro. 2--Endoloronchial obstructins cudothelial tumor in a man, azed thirty-five zears, who cornplainer of coughing, wheezing, and " a sensation as of a lall valte ahutting off his breath, sometimes on ingpiration and at other times on cxpiration. $B$, bronchoscopic view dontn right main bronchus. $A$, tumor presentine ituelf in its self-made bronchial entnsemeat. when tho bronchoscopic tube-mouth reached the loeation at which the vicw $B$. should nppear. Tumor removed with foreps through a hronchoscope passed through the mouth. Patient free from symptomg at ead of three weeks and remained perfeetly well a sen a ad a hall later. 
the supporting tissues in suclu a way as to suggest maligntucy. Iatter eximination of paraflin sections only confirms original opinion."

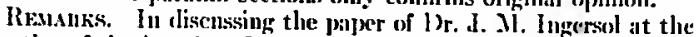
meeting of the Anerican In aryngological Asseciation in I914, I spoke against the attempit at bronchoscopic removal of entotracleal maligunncy; and snch being my convietim, I wonkl not have removed the endobronchial growth in the present ense laid I not felt it the time that it wis benign. 'The present condition of the patient, however, indicates that I)r. Ingersol's position as to the possibilities of bronchoseopic removal mily he nearer right than my own, though lie referred only to tricheal growths, while my case wals bronchial. It wonld not lie right, lawerer, on the hasis of this uniogne casce, to sinction the indiseriminate bronchoscopic attack of pulmonary malignance: It seems scarcely possible, bronchoseopieally, to remove malignancy completely in many instanees; and we all kinow only too well the resilts of pirtial removil elsewhere. So fir as the present ease is to be taken for guiclanee, it cant apply ouly to a sharply circmn-

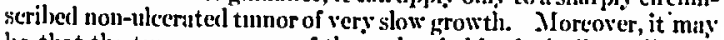
be that the tumor was one of those thit is histologically. inalignant and dinienlly benigu. Or, it may be that it was of a very low degree of malignancy, for we kuow that there are degrees of miligninucy or of individual vuhnerability; and, as stater hy Wright, it is not possille to make a prognosis from the listological examination of a growtl. Finally, we kiow that recurrence is yet possille. In view, however, of the very great rarity of the case and the necessity for us all to be alert to tle possililities of diagnostic bronchoseopy, louger delay in inaking this report seemed innd visable, especinlly in view of the fact that the present condition of the paticut and his moutlis of perfect healtl, fully justifiel the relatively minor operistion under local anesthesia, even if the growtl ultinately recurs."

Coxcucsioss. 1. Diagnostie bronchuscopy is indieted in enses of monolateral "astluma," bronchitis, bronchiol olstruetion, nul in cises of tubercnlosis where persistent semreh fails to slow tuhercle bacilli.

2. Peroral bronchoscopic removal of an endobronchial tmmor is feasible under local anesthesia.

3. General anesthesin might have permitterl chotting of blool in the lower bronehi before bechic expulsion, involving septic risk.

4. Peroral bronchoscopic removal may be justifiable in al maligniant eudobronchial grow'th if small, circunscriberl, and not nkeristed.

i. As this is the only reeoriled caise of apparent cure of an endothelial enclobronchial tumor by jeroral bronchoscopy, and only: the second endoseopic removial of any form of malignant growtl from a lironehus, it wonkl be umwise to make too inaluy or too sweeping deductions.

\footnotetext{
:One and one-half years have now elapsed ant the palionl is in perfecl heal(h, without erpectoracion or any other symplom.
} 